\title{
Impacts of Urban Sprawl on Livability in Kaduna Metropolis, Nigeria
}

\author{
Nuhu H. Tini, Bartholomew Joshua Light \\ Adamawa State University Mubi, Department of Geography, Nigeria
}

\section{Article Info}

Volume 7, Issue 6

Page Number : 334-343

Publication Issue :

November-December-2020

\section{Article History}

Accepted : 04 Dec 2020

Published : 10 Dec 2020

\section{ABSTRACT}

Urban sprawl is a global phenomenon in the contemporary era. It is mostly taking place in the less developed countries due to natural increase and consistent movement of people into the mega cities and large urban centers. The phenomenon has globally gained attention from diverse researchers in the field of urban geography, environmental studies, city and region planning in view of its significant influence on the urban environment. However, the effect of sprawl on urban livability and economy in Nigerian cities is scarcely investigated especially in Northern Nigeria. This research explores the social and economic effects of urban sprawl in Kaduna metropolis. Remote Sensing and Geographic Information System (GIS) Technologies were applied for the analysis. The study found that Kaduna metropolis has experienced a progressive increase in the built-up area; in 2006 it had an aerial coverage of 13,980 hectares, a rise of 107.91\% from 2001 aerial coverage of 6724 hectares. In 2012, the city had an aerial coverage of 15,808 hectares, an increase of $13.08 \%$ from 2006. Conversely, there has been a remarkable decrease in percentage of vegetation (1,458 hectares) and agricultural (11,739 hectares) land areas. In turn, such changes has adversely affected urban facilities or utilities such as pipe-borne water, electricity, health facilities, schools, security, transportation, wastewater infrastructures and fire safety services, which has become overstressed. Economic crisis has manifested in the rise of unemployment and escalating number of urban poor. Residential land use has encroached into open spaces while commercial activities overrun residential areas. Increase in distance and journey time make travel cost unbearable to the common man. These and social fragmentation retard livability in the city. Thus calls for a balance sustainable development in Kaduna metropolis and effective management of urban growth by the Kaduna Capital Development Board Authority. In due course, smart growth policy, growth management, urban containment, effective land use planning and public facility adequacy have been recommended to foster viable urban growth in Kaduna city and elsewhere.

Keywords: Analysis, Geographic Information System, Urban Sprawl, Livability, Kaduna Metropolis 


\section{INTRODUCTION}

Growth of urban areas has become a global phenomenon. Cities and towns are continuously growing and blooming with changes in land use along the highways and in the immediate vicinities (Sudheira et al, 2009). Such growth is known as sprawl and is described as a response to habitual bewildering sets of economic, social and political forces and to physical geography of an area (Theobald, 2001). Urban sprawl is aligned to historical, geographical and cultural factors. It is also caused by improper planning, inadequate policy decisions, lack of good governance, population growth, economy, and patterns of infrastructure initiatives like the construction of roads and the provision of infrastructure which in turn encourage development (Sudhira et al, 2009).

Livable environment integrates physical and social well-being to sustain a productive and meaningful human existence in urban areas (Asia-Pacific Economic Cooperation, 2015). However enormous expansion of cities threaten the economic, social and environmental quality which consequentially retard urban livability. The environmental consequences of urban sprawl are numerous. These include spoilage of landscape, damage of ecological functions, loss of agriculturally-based livelihoods, overspill of suburbs, increased demand for mobility, traffic congestion and rising ecological burdens such as land development, pollutant burdens, noise emissions, criminality, urban violence, urban warfare (Chivot, 2011). The aforementioned consequences of urban sprawl can be determined in diverse ways. Eight dimensions of urban sprawl are usually measured. These comprise density, continuity, concentration, compactness, centrality, nuclearity, diversity, and proximity. Such dimensions are measured by apportioning urban areas into one-mile grids by the means of combining GIS and field investigation (Galster et al. 2000). However, some drawback have been acknowledged in using the dimensions, especially in comparative assessment of metropolitan sprawl areas (Lopez and Hynes 2003). Some simple measures of sprawl comprise population density, dwelling unit density, or job decentralization gauge. Though, Bourne (2001) notes, demographics that identify cohorts of population in urbanization are more important measures of the changing urban form. Aerial photography is commonly used in collecting spatial data, depicting, and defining urban sprawl qualitatively and quantitatively as features of a single connected system (Hayden, 2004). The changing aspects of urban sprawl can be captured by using satellite imagery/remote sensing especially with Landsat data in comparing the growth of metropolitan regions (Masek and Lindsay 2001).

GIS is used in conjunction with multi-criteria analysis (MCA) to define suitable areas for future urban expansion. This is a kind of hybrid method that forecasts sprawl in unplanned urban growth. The hybrid methodology describes likely development patterns, but the MCA does not provide criteria with which urban sprawl is assessed. The Leadership in Energy and Environmental Design (LEED-ND) rating system advanced by U.S. Green Building Council is used to assess neighborhood development. This method rates the features that are generally lacking in the sprawl city's typical suburban. However, the rating systems do not supply any consequences of low rankings which are linked to sprawl.

Smart growth index (SGI) is used for mapping environmental impacts of existing building and infrastructure. This helps in local government surveys of likely future scenarios by evaluating changes in new development and transportation (EPA, 2003). 
The spatial analyst in ArcGIS software is used to accomplish tasks similar to the SGI. For example, complex decisions such as where to build and expand in cities (Barnett, 2007).

The concept of '3Es' - discussions on the consequences of urban sprawl in ecologic, economic, and equity (ecologic-economic-equity-3Es) and analysis of the spatial patterns and sprawl of cities have become crucial issues globally (Sudhira et al, 2009; Banai and DePriest 2014). Such help in understanding the nature and growth of urban areas which aid in evolving any policy and management options for effective control of the problems associated with urban sprawl. Earlier visualization of the trends and patterns of urban growth enable planning machineries to design for appropriate basic infrastructure facilities such as water, electricity and sanitation. The study of type, extent, nature and effect of sprawl occurring in a place and the drivers responsible for the growth as well help developers and town planners to project the growth patterns, the consequences of urban sprawl and facilitate the provision of various infrastructure facilities needed.

Effective urban planning and management practice is imperative in order to forestall further unplanned urban growth in cities. However, planning and managing urban sprawl have become difficult tasks in Nigerian cities. This is peculiar in dealing with issues like water and air pollution, erosion, flooding, and unpleasant odour which occur due to improper physical planning (Okosun et al, 2009). Kaduna metropolis has witnessed a remarkable evolution in terms of population explode and developmental activities such as housing, road construction, deforestation and other anthropogenic activities. These activities have resulted to increased land consumption and modification in land use-land cover which threaten urban livability. There has never been any detail and comprehensive assessment of such changes in the metropolis. The only attempt made was by Akpu et al (2017), who analyzed the extent to which the spatial growth of Kaduna city is responsible for vegetation loss. Bununu (2011) and Ndabula et al (2014) also examined the growth patterns of Kaduna metropolis. Bununu et al (2015) predicted the future urban growth in Kaduna. All of these studies are silent about the form, sources, properties and implications of sprawl on livability in the metropolis. This rapid transformation of Kaduna metropolis and its attendant repercussion predicate the present research. The study intends to investigate the dynamics, causes, and the effects of urban sprawl on livability in the metropolis.

\section{METHODS AND MATERIAL}

\section{A. THE STUDY AREA}

Kaduna drew its name from the major river (River Kaduna) which dissect the city. The term originated from the Hausa word "Kada" which means crocodile. Hence, "Kaduna" is a plural name for Kada (Apku et al 2017). The town was established by the British colonial administration in 1912 (Haruna, 2012).The Metropolis occupies a very strategic position in the contemporary history of Nigeria; because in 1919, Kaduna was made the regional capital of the defunct Northern Nigeria Protectorate. Subsequently, the city kept on expanding both in population and spatial extent. Kaduna grew from a small town of 35,000 in 1950 and 250,000 residents in 1963, to $1,307,311$ in 1991(Census, 1991) and more than 1.5 million today (Tony, 2018). By 1985 and 2010, Kaduna's spatial extent was respectively estimated at $140 \mathrm{~km} 2$ and $420 \mathrm{~km} 2$ (Agunbiade et al., 2012). Currently, almost 200 ethnic groups of Nigeria dwell in Kaduna city. About $70 \%$ of the entire population are traders, retirees, private company workers and civil servants, while $3 \%$ are peasant farmers. Kaduna metropolis roughly lies on Latitudes $10^{\circ} 20^{\prime} \mathrm{N}$ and $10^{\circ} 37^{\prime} \mathrm{N}$ of the Equator and Longitudes $7^{\circ} 22^{\prime} \mathrm{E}$ and $7^{\circ} 31^{\prime} \mathrm{E}$ of the 
Greenwich meridian (see figure 1). It occupies a total land mass estimate of $46,026 \mathrm{~km} 2$.The city is surrounded by scattered farmland settlements. Kawo and Mando border the city to the North. Romi, Television Gonin and Gora to the South. While to the East is river Kaduna and to the West are Rigasa and Kabala. The metropolis is divided into Kaduna North and Kaduna South Local Government Areas, adjoined by Igabi and Chikun Local Government Areas respectively.

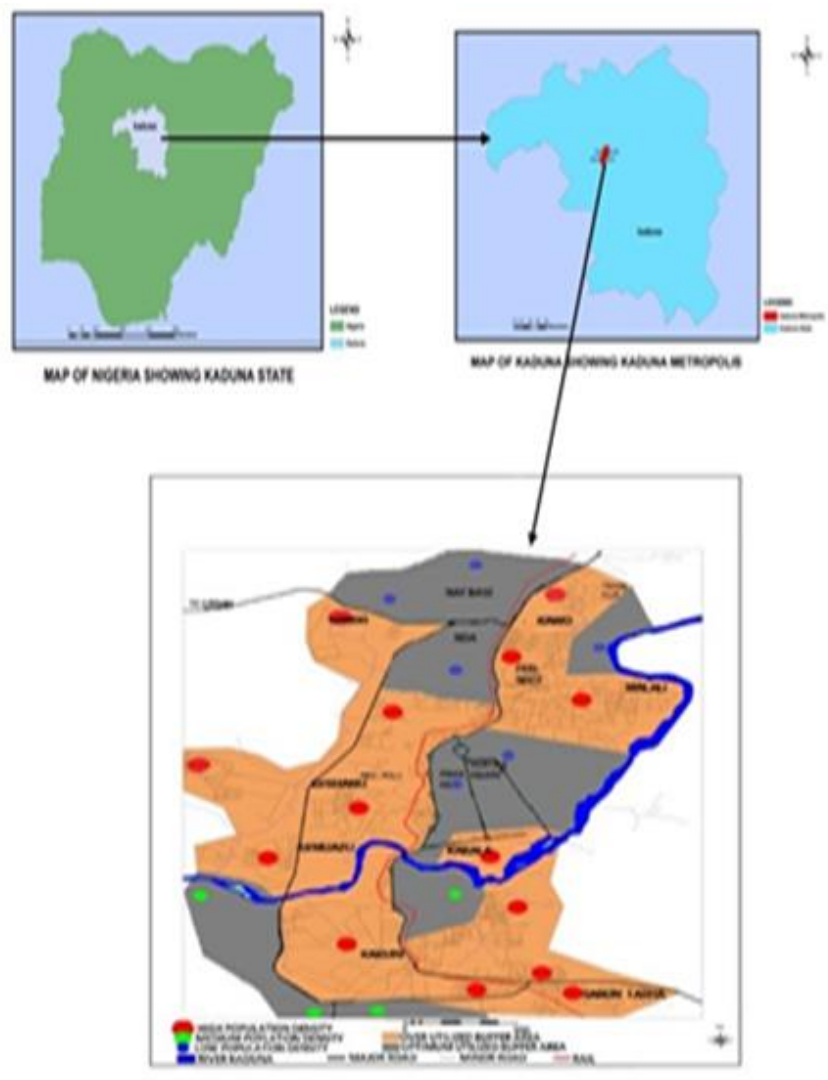

Figure 1: The Study

\section{B. METHODOLOGY}

The spatial data for this reseaerch were obtained from Multi spectral and Thematic Mapper Sensor on board both Landsat 5 and Landsat 7 Satellite Sensors. GIS software were used for treating LandSat satellite images of 2001, 2006 and 2012 as presented in Table 1. Such imageries were resampled, georeferenced and the required information were digitize in ArcGIS 9.2. Then ILWIS 3.3 was used for development of land use-land cover classes and subsequently for change detection analysis in the study area. The land uses in Kaduna city were classified into five categories; including built up or urban area (residential, commercial, industrial, paved and unpaved road), bare land, water body, vegetation and agricultural farmland. Visual image analysis and interpretation were used to identify and arrange land uses into classes as required. Satellite imageries of the city were separately processed, enhanced, classified, vectorized and converted into polygon for three (2001, 2006, 2012) different years within the period of this study. The results were then overlaid to show the extent and growth of urban area in Kaduna metropolis over the years. The generated Land use-land cover data was used for calculation of land use percentage change (PC) over the period of study. The formula PC = $\left(\frac{\mathrm{v} 2-\mathrm{v} 1}{\mathrm{v} 1}\right) \times 100$ by Kenton (2019) was used to calculate the percentage change. Information on the implications of sprawl on urban livability were generated through field survey and verbal interviews with Kaduna city planning officials and the urbanites.

Table 1: Satellite Imageries Used

\begin{tabular}{|l|l|l|l|}
\hline Data Type & $\begin{array}{l}\text { Spatial } \\
\text { Resolutio } \\
\mathbf{n}\end{array}$ & $\begin{array}{l}\text { Date } \\
\text { of } \\
\text { Manuf } \\
\text { acture }\end{array}$ & Source \\
\hline $\begin{array}{l}\text { LAND SAT } \\
\text { TM }\end{array}$ & $30 \mathrm{M}$ & 2001 & GLCF \\
\hline $\begin{array}{l}\text { NIGERIA } \\
\text { SAT-1TM }\end{array}$ & $32 \mathrm{M}$ & 2006 & $\begin{array}{l}\text { NCRS/NASR } \\
\text { DA }\end{array}$ \\
\hline $\begin{array}{l}\text { NIGERIA } \\
\text { SAT-X }\end{array}$ & $32 \mathrm{M}$ & 2012 & $\begin{array}{l}\text { NCRS/NASR } \\
\text { DA }\end{array}$ \\
\hline
\end{tabular}




\section{RESULTS AND DISCUSSION}

\section{A. URBAN SPRAWL IN KADUNA CITY}

This study assessed urban sprawl in Kaduna metropolis for a period of twelve (12) years from 2001 to 2012. Table 1 displays the outcome of land use coverage within Kaduna metropolis in 2001. The result in the table attests that urban area covered only 6,724 hectares (7.7\%) of the total landmass of Kaduna metropolis in 2001. Agricultural farmland enclosed the highest $(56.8 \%)$ while vegetation had the next highest (29.5\%) land coverage. This result implies that Kaduna city size was much less than the farmland and vegetation land in 2001.

The visual size and pattern of Kaduna metropolis in 2001 is presented in Figure 2. This map reveals that the pattern of urban growth was star-like or radial form. Consequentially the origin and initial growth of Kaduna as an urban centre is not unconnected with its earlier administrative function as a regional head office, provincial headquarters and state capital, as well as an educational and commercial centre. However, Ndabula et al (2014) observed that the high rate of urban sprawl experienced between 1967 and 1987 in Kaduna city is attributed to industrial development which coincided with the period of rapid industrialization in Nigeria. The number of manufacturing establishment in the city grew from 6 in 1960 to more than 300 in 1985 (Lloyd-Jones, 2018).
Table 1: Land Use Coverage in Kaduna Metropolis (2001)

\begin{tabular}{|l|l|l|}
\hline Year & \multicolumn{2}{|l|}{2001} \\
\hline Class & $\begin{array}{l}\text { Areas in } \\
\text { Hectares }\end{array}$ & $\begin{array}{l}\text { Percent } \\
\text { Coverage }\end{array}$ \\
\hline Urban Area & 6,724 & $7.7 \%$ \\
Bare Land & 3,704 & $4.3 \%$ \\
Water Body & 1,485 & $1.7 \%$ \\
Vegetation & 25,624 & $29.5 \%$ \\
Farmland & 49,286 & $56.8 \%$ \\
& & \\
\hline
\end{tabular}

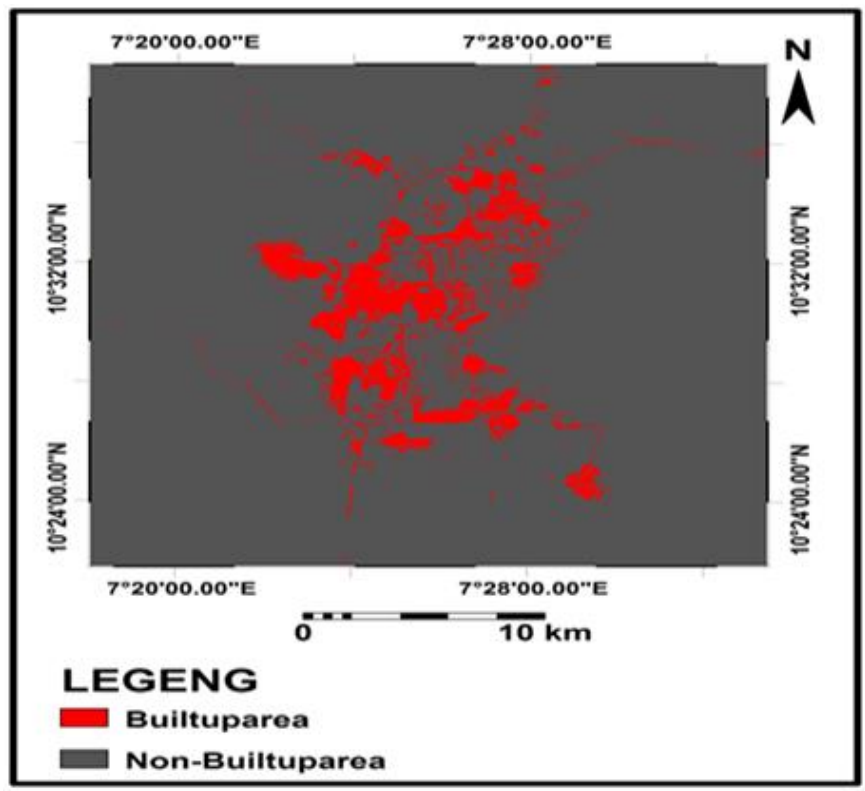

Figure 2: Spatial Extent of Kaduna Metropolis (2001)

The changes in land use coverage within Kaduna metropolis over the period of 2001-2006 is illustrated in Table 2. The result indicates that urban area increased by (7, 256 Hectares) almost $107.91 \%$ in 2001-2006. Conversely, the hectare coverage of bare soil, water body, vegetation and agricultural farmland kept on reducing by $-22.87 \%,-24.04 \%,-12.93 \%$ and $5.55 \%$ respectively over the period of the study. It is vividly clear that enormous changes occurred in land 
use coverage between the year 2001 and 2012. Builtup area gained while the other type of land uses lost significant percentage coverage.

Table 2 : Land Use Change in Kaduna Metropolis,

\begin{tabular}{|c|c|c|c|}
\hline \multicolumn{4}{|c|}{$2001-2006$} \\
\hline Year & 2001 & 2006 & \\
\hline Class & $\begin{array}{l}\text { Areas in } \\
\text { Hectares }\end{array}$ & $\begin{array}{l}\text { Areas in } \\
\text { Hectares }\end{array}$ & $\begin{array}{l}\text { Percent } \\
\text { Change } \\
2001 \text { - } 2006\end{array}$ \\
\hline Urban & 6,724 & 13,980 & 107.91 \\
\hline Area & 3,704 & 2,857 & -22.87 \\
\hline Bare Land & 1,485 & 1,128 & -24.04 \\
\hline $\begin{array}{l}\text { Water } \\
\text { Body }\end{array}$ & 25,624 & 22,310 & -12.93 \\
\hline $\begin{array}{l}\text { Vegetation } \\
\text { Farmland }\end{array}$ & 49,286 & 46,553 & -5.55 \\
\hline
\end{tabular}

The spatial extent of Kaduna metropolis in 2006 is presented in Figure 3. The map clearly shows a continuous sprawl (13,980 hectares) of Kaduna metropolis especially towards the northern and southern fringes in 2006. Traces of in-fill developments occurred in the metropolis over this period which made the city more clustered The rapid growth experienced in the metropolis between 2001 and 2006 is supposed not unconnected with the 2001 Kaduna ethno-religious crisis. This led to residential segregation based on religious dominance of the city regions. Consequently, Christians migrated toward the south, while Muslims resettled to the north of the city. The industrial layout situated south of the city also contributed to southern expansion of the metropolis as earlier mentioned. Construction of Kaduna bye-pass south of the city to link Kaduna and
Abuja has also resulted to the southward spatial sprawl of the metropolis.

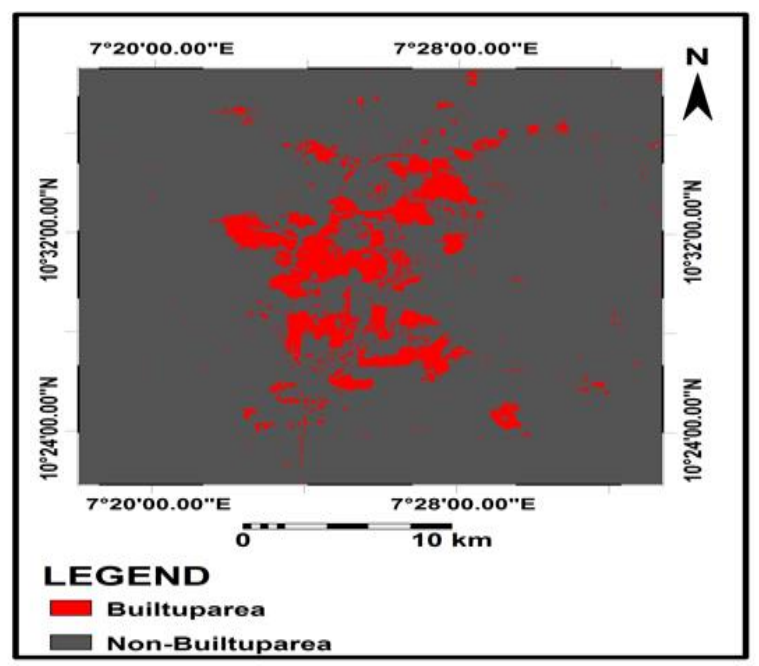

Figure 3: Spatial Extent of Kaduna Metropolis (2006)

Table 3 presents the land use coverage of Kaduna metropolis in 2001. It reveals that built-up area (city size) expanded to 15,808 hectares in 2006-2012, a $13.08 \%$ increase. This is almost twice higher than the city size in 2001. Water body experienced the highest (39.18\%) percentage increase. Bare land and farmland drastically reduced by $-42.11 \%$ and $-19.35 \%$ respectively.

Table 3 : Land Use Change in Kaduna Metropolis, $2006-2012$

\begin{tabular}{|l|l|l|l|}
\hline Year & 2006 & 2012 \\
\hline Class & $\begin{array}{l}\text { Area in } \\
\text { Hectares }\end{array}$ & $\begin{array}{l}\text { Area in } \\
\text { Hectares }\end{array}$ & $\begin{array}{l}\text { Percent } \\
\text { Change } \\
\text { 2006-2012 }\end{array}$ \\
\hline Urban & 13,980 & 15,808 & $13.08 \%$ \\
Area & 2,857 & 1,654 & $-42.11 \%$ \\
Bare Land & 1,128 & 1,570 & $39.18 \%$ \\
Water & 22,310 & 24,166 & $8.32 \%$ \\
Body & 46,553 & 37,547 & $-19.35 \%$ \\
Vegetation & & & \\
Farmland & & & \\
\hline
\end{tabular}


The spatial extent of Kaduna metropolis in 2012 is illustrated in Figure 4. The map confirms that more intensive in-fill developments occurred within Kaduna metropolis in 2012. More new suburb settlements emerged in the North-east, North-west and South east of the metropolis. Inevitable reaction against unacceptable conditions such as conflict, crimes, crisis, poor health, and low quality of life is believed to have pushed people out of the city to develop shelter in the peripheral areas. Hence the suburbs became uncontrolled which in turn generated haphazard location of structures without planning guidelines, facilities and services.

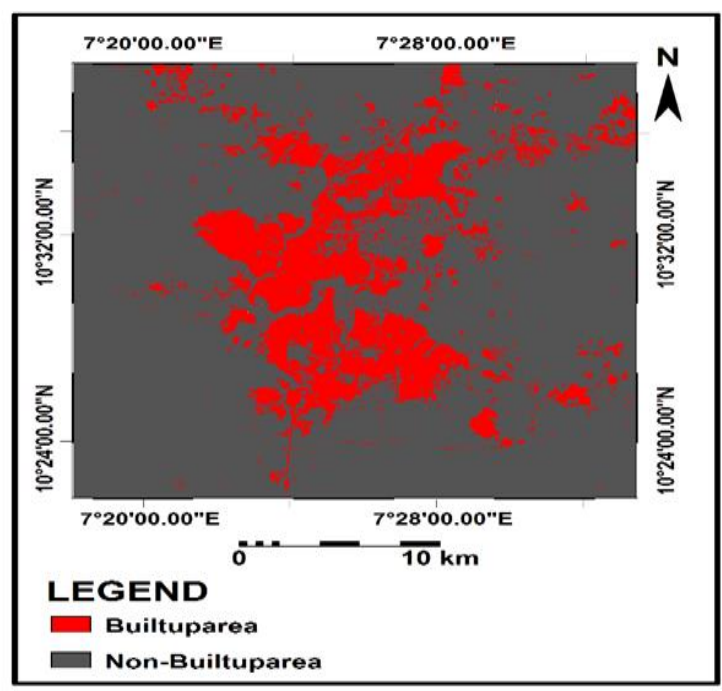

Figure 4: Spatial Extent of Kaduna Metropolis (2012)

The increase in physical growth of Kaduna Metropolis between the periods of 2001 and 2012 is demonstrated in Figure 5. This progressive rise in spatial growth foretells that the town continuously kept on expanding outward. The city size increased greatly towards the north and the southern regions. The result reveals a lesser outward expansion in 2012. Such tendency could be aligned to the in-filled development that manifested within this period. However, Ndabula et al (2014) opined that the economic recession experienced in Nigeria was responsible for the slower rates of growth in Kaduna metropolis.

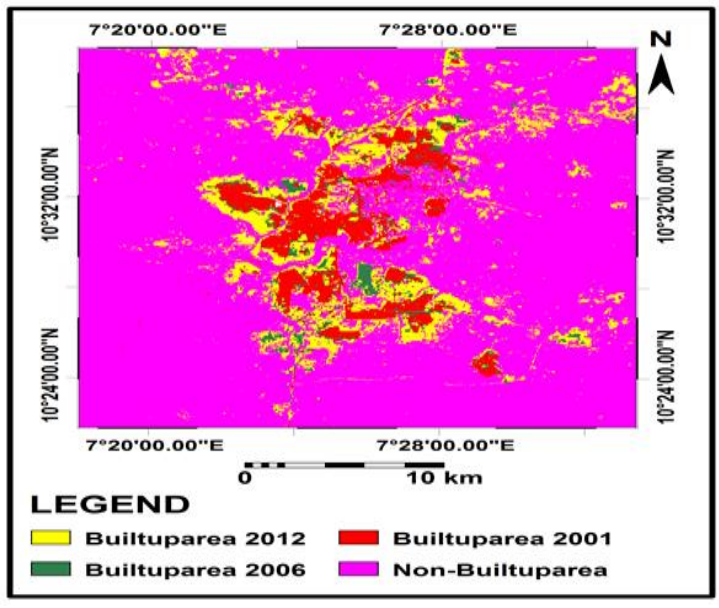

Figure 5: Over-lay of Built-up Areas in Kaduna Metropolis (2001, 2006 and 2012)

\section{B. IMPLICATIONS OF SPRAWL ON LIVABILITY IN KADUNA METROPOLIS}

The progressive spatial growth of Kaduna metropolis has generated a number of physical, social and economic changes in the city. It has also led to increase in energy consumption and effluents from diverse human activities that in turn damage social sustainability, public health, safety and environment. Such circumstances has imposed negative effect on everyday lives of the residents - urban livability. In consequence, much of what was initially considered as the major profits of urban life, such as security, better housing and public service have become untenable. The repercussions of sprawl on livability in Kaduna municipal manifest in numerous ways which includes the followings:

Infrastructure, Facilities and Utilities Threat. As population increases, the demand for infrastructure continuously rises in Kaduna city. This made the available facilities, utilities and services to become overstressed such as pipe-borne water, electricity, health facilities, schools, security and fire safety services. Many neighborhoods in the city are presently facing crisis with their electrical, transportation and wastewater infrastructures which 
are seriously either obsolete, insufficient or overburdened. Such pressing demand for amenities result to dramatic consequences for the urban population. Another bitter experience by the urbanites is the increasing demand for recreation, safe housing and mobility. In consequence, both the state and local governments require more funds to provide additional facilities and infrastructure such as electricity lines, roads, refuse collection site, water and sewer in the overcrowded slums and new suburb areas. The planning authority also find it difficult to regulate building standard and implement zoning in such affected areas.

Socio-Economic and Socio-Political Perils. Kaduna city sprawl is characterized by population upsurge, accompanied by economic crisis which manifests in the rise of unemployment escalating the number of urban poor in Kaduna metropolis. Table 4 reveals that unemployment rate increased in Kaduna between 2001 and 2010 with about $12.4 \%$ in 2010 (Knoema.com, 2010), while it rose to $26.8 \%$ in 2018 and 30.0\% in 2019 (National Bureau for Statistics, 2019). As a result, in 2010, the skilled and semiskilled economic activities accounted for $24.9 \%$ while self-employed accounted for $58 \%$ workforce in the city (Lloyd-Jones, 2018). The sprawl as well contributed to rise of diverse urban cultures, adding to the existing spatial, socio-economic segregation and ethnic tensions. Kaduna city has repeatedly experienced explicit ethno-religious crisis since 2000 (Refworld.org Report, 2003). Such has been attributed to the human diversity and cultural pluralism brought by urban expansion and population explosion in the city. This situation has generated severe consequences on peace and security in Kaduna metropolis over the years.
Table 4: Fluctuations of Unemployment in Kaduna

\begin{tabular}{|c|c|c|c|c|c|}
\hline \multicolumn{6}{|c|}{ Kaduna - Total Unemployment Rate } \\
\hline Date & Value & $\begin{array}{l}\text { Change } \\
\text { (\%) }\end{array}$ & Date & Value & $\begin{array}{l}\text { Change } \\
\text { (\%) }\end{array}$ \\
\hline 2010 & 12.40 & $6.90 \%$ & 2004 & 15.90 & $\begin{array}{l}-18.88 \\
\%\end{array}$ \\
\hline 2009 & 11.60 & $\begin{array}{l}-8.66 \\
\%\end{array}$ & 2003 & 19.60 & $\begin{array}{l}133.33 \\
\%\end{array}$ \\
\hline 2008 & 12.70 & $\begin{array}{l}45.98 \\
\%\end{array}$ & 2002 & 8.40 & $\begin{array}{l}21.74 \\
\%\end{array}$ \\
\hline 2007 & 8.70 & $\begin{array}{l}-38.30 \\
\%\end{array}$ & 2001 & 6.90 & $\begin{array}{l}-64.62 \\
\%\end{array}$ \\
\hline 2006 & 14.10 & $\begin{array}{l}16.53 \\
\%\end{array}$ & 2000 & 19.50 & $\begin{array}{l}186.76 \\
\%\end{array}$ \\
\hline 2005 & 12.10 & $\begin{array}{l}-23.90 \\
\%\end{array}$ & 1999 & 6.80 & \\
\hline
\end{tabular}

Source: Knoema.com (2010)

Loss of Natural Habitat and Biodiversity. The outward growth of Kaduna metropolis has consumed enormous percentage of vegetation (1,458 Hectares), virgin (2,050 Hectares) and agricultural (11,739 hectares) lands. This has in turn resulted to the destruction of natural habitat and biodiversity in the city's vicinity. Thus the available arable and farming lands have been reduced by - \% over the years. Whereas the remaining urban ecosystem is overloaded. This triggered the loss of agriculturallybased livelihoods and restricted access to natural ecology in Kaduna metropolis.

Land Management Risk. Invasion of land uses due to unguided growth persistently occur as residential land use encroach into open spaces in Kaduna city. Commercial activities also overrun residential areas. This often result to land disputes among the inmigrants and the natives. Conversion of residential areas into churches and mosques is noticed around Sabon Tasha, Television in the south and Tudunwada 
in the northern part of the metropolis. The railway at Kukari is also infringed by residential developers. Such activities has led to the proliferation of informal and unplanned urban settlements, that is, slums or ghettos. This in turn causes threat to effective land management in Kaduna Metropolis.

Traffic Congestion and Pollution. High volume of traffic is often experienced at Tudunwada and the central area of Kaduna metropolis particularly during morning and late evening hours. This is caused by rise in movement to the city of great number of people who reside in the fringes and work, transact business or engage in social activities at the city centre. Such traffic jams are often associated with fumes, noise and accidents which tend to afflict and in-comfort localities, streets and pedestrians. In addition, housing developments are located close to motorway networks. As a result, the residents are exposed to persistent high levels of traffic noise that impair business productivity and cause permanent damages on health such as heart attacks and strokes.

Travel Distance and Transportation Cost. Urban sprawl has prompted dependence on motor vehicles due to increase in distance and journey time in Kaduna city. Travel cost to the suburb areas has become unbearable to the common man. At an average rate of about 6 naira per kilometer. A commuter that resides in Rigachikun and works in the city centre spends an average of N200 to get to work and back home on a daily basis. This translates into an unhealthy sum of N6, 000 a month in the city. Transportation cost also manifests in increased pollution emissions which worsen air quality in the metropolis. Harmful gases such as Carbon Monoxide, (Co), Hydrocarbons (Hc), Nitrogen Oxide $\left(\mathrm{NO}_{2}\right)$ and particulate matters like dust, smoke and lead are injected into the atmosphere by diverse ever increasing number transportation modes and human activities.
Health and Safety Hazard. Sprawl has attracted more human activities that generated high rates of the earlier mentioned pollutant gases which are detrimental to human health and the environment in Kaduna city. IQAir and Greenpeace (2018) ranked Kaduna city $8^{\text {th }}$ on the list of 20 worst polluted cities in the world measured by PM10. Such pollutants are the main cause of the rise in chronic diseases such as asthma, allergies, cancer, emphysema, impaired hearing and visibility or body disorders in cities today. Additionally, the high levels of traffic noise associated with the rise in urban population and mobility lead to poor visibility and permanent damages on health such as heart attacks and strokes.

Population and Delinquency Explode. Urban sprawl has generated rise in urban population in Kaduna city. The city underwent extreme urban population expansion and grew from a small town of 35,000 in 1950; 42, 64 in 1952, and 129, 133 in 1963 to metropolis of 1.5 million today (Imoagene, 1978); Lloyd-Jones, 2018). Between 1965 and 2015 the population of Kaduna's urbanized area increased six (6) fold (Lloyd-Jones, 2018). This population growth emanated from natural increase, in-migration and overcrowding of people with different social and cultural background. Such population explode threatens urban quality of life in Kaduna city as it attracts diverse kinds of delinquency. Thereby making the system vulnerable, as the high human density become exposed to socio-economic and environmental changes. Thus manifest in proliferation of slums areas, air and environmental pollution. It has also led to severe consequences for security such as urban violence, criminal activities and low quality of life in the city. The poor urban districts significantly experience greater levels of criminality. In slum areas, crimes such as homicide, robbery, burglary, corruption, drug, arms and human trafficking and kidnapping are time and again the main cause of high mortality rates. 
Loss of Social Cohesion. Social fragmentation has emanated from deprivation, otherness, racial discrimination, social and class based segregation concepts. This situation greatly retards social unity in Kaduna metropolis. The urban space pattern has been divided into diverse districts with respect to the housing areas which also generated social and class segregation or diversity. In addition, important part of road transportation networks in the city remains inaccessible for the disabled and the elderly. This makes it difficult for such category of people to attain optimum interaction and thus seriously damage social cohesion and equity in Kaduna city.

\section{IV.CONCLUSION}

This study assessed the influence of physical configuration on livability in Kaduna city. In view of the diverse repercussions inflicted on livability by urban sprawl in the metropolis, we recommend the following strategies to curtail and manage the menace of such phenomenon. First and foremost, the most widely accepted smart growth policy is commended. This approach is where development should be guided in an efficient and effective way to minimize infrastructure costs and environmental impacts so as to maximize quality of life for urban residents. The technique entails providing for growth (both economic and population) while at the same time restraining the adverse effects of sprawl. Another strategy recommended is the growth management approach. This strategy is to place emphasis on preserving environmental resources by setting limits on new development and thus controlling future growth. Such policy is expedient for safeguarding cultural heritage and providing recreation functions. We further recommend other measures to be incorporated such as urban containment, transportation efficient land use planning and public facility adequacy. Integration of policy mix of economic and planning strategies, with right cooperation within and between levels and effective implementation would foster sustainable urban growth in the city and elsewhere.

\section{REFERENCES}

[1]. Agunbiade, M.E., Rajabifard A., and Bennet R., (2012). The Dynamics of City Growth and the Impact on Urban Land Policies in Developing Countries. International Journal of Urban Sustainable Development, 4:2, 146-165.

[2]. Apku, B., Adamu, I. T., David, N. J., \& Bala, D., (2017). Geospatial Analysis of Urban Expansion and Its Impact on Vegetation Cover in Kaduna Metropolis, Nigeria". Asian Journal of Environment \& Ecology 3(2): 1-11, 2017; Article No. AJEE.31149 ISSN: 2456-690X).

[3]. Banai, R. and DePriest, T. (2014). Urban Sprawl: Definitions, Data, Methods of Measurement, and Environmental Consequences. The Journal of Sustainability Education, December 18Th, 2014 http://susted.com.

[4]. Bununu, Y. A., Ahmad Nazri Muhammad Ludin, A. N. M., and Hosni, N., (2015). Integration of Logistic Regression and Markov Chain Analysis in Modelling and Predicting Future Urban Growth in Kaduna, Nigeria. Paper presented at the 9th South East Asia Technical University Consortium (SEATUC) Symposium 27-30 JULY 2015 Suranaree University of Technology Nakhon Ratchasima Thailand.

[5]. Chivot, Eline (2011). Livability and Sustainability in Large Urban Regions. The Hague Centre for Strategic Studies and TNO.

[6]. Haruna, M., (2012). People and Politics: A (Brief) History of Kaduna: The City of Crocodiles. http://www.gamji.com/haruna/haruna251.htm.

[7]. Imoagene, Oshomba (1978). Migrating into Unemployment and Poverty: Some Consequences of the Urban Revolution in Nigeria Africa Development / Afrique et 
Développement Vol. 3, No. 1 (January - March 1978 / Janvier - Mars 1978), pp. 53-64 (12 pages)

Published

By:

CODESRIA.https://www.jstor.org/stable/2448632 9

[8]. Kenton, Will (2019). Percentage Change Investopedia. www.investopedia.com.

[9]. Knoema.com (2010). Kaduna - Total Unemployment

https://knoema.com/atlas/Nigeria/Kaduna/Unem ployment-rate

[10].Lloyd-Jones, Tony (2018). Urban Change in a Northern Nigeria City: Kaduna 1965 - 2015. Urbanization Research Nigeria Conference 12 13 March 2018, Shehu Musa Yar'Adua Centre, Central Business District Abuja.

[11].Ndabula, C, Jidauna, G. G., Averik, P. D., Oyatayo, T. K., Abaje, I. B., Ali, A.Y. (2014). Characterization of Sprawling in Kaduna Metropolitan Area. American Journal of Environmental Protection. Vol. 3, No. 3, pp. 131137. Doi: 10.11648/j.ajep.20140303.14.

[12].Okosun, A. E. et al (2009). Urban Growth Management of Nigeria Cities: A GIS Approach. In Journal of Environment and Safety (JEMS). Journal homepage: www.cepajournal.com.

[13]. Oyedele O. E (1987). Colonial Urbanization in Northern Nigeria: Kaduna 1913-1960. Unpublished $\mathrm{Ph}$. D Thesis, Department of History, Ahmadu Bello University, Zaria.

[14].Refworld.org Report (2003). The Miss World Riots: Continued Impunity for Killing in Kaduna https://www.hrw.org/reports/2003/nigeria0703/2.

[15].Sudhira, H. S., T. V. Ramachandra, T. V., \& Subrahmanya M. H. B., (2009). Urban Sprawl Management: Need for an Integrated Spatial Planning Support System. Technical Report_200707 Doc.

[16].Theobalb, D.M. (2001). "Quantifying Urban and Rural Sprawl Using the Sprawl Index". Paper Presented at the Annual Conference of the
Association of American Geographic in New York on March 2nd 2001.

[17].Tini, N. H., (2011). The Use of Remote Sensing and GIS for Appraisal of Spatial Growth in Mubi Metropolis, Adamawa State University, Mubi. In Continental J. Environmental Design and Management. http://www.WiloludJournal,com.

[18].Tony, L. J., (2018). Urban Change in a Northern Nigeria City: Kaduna. A Paper presented at Urbanization Research Nigeria Conference, 12 13 March 2018, Shehu Musa Yar'Addua Centre Central Business District Abuja.

\section{Cite this article as :}

Nuhu H. Tini, Bartholomew Joshua Light, "Impacts of Urban Sprawl on Livability in Kaduna Metropolis, Nigeria", International Journal of Scientific Research in Science and Technology (IJSRST), Online ISSN : 2395-602X, Print ISSN : 2395-6011, Volume 7 Issue 6, pp. 334-343, November-December 2020. Available at doi : https://doi.org/10.32628/IJSRST207644 Journal URL : http://ijsrst.com/IJSRST207644 